\title{
Multilingualism and Identity: Polish and Russian Influences in German Rap
}

\author{
ALEKSEJTIKHONOV, Humboldt University
}

\begin{abstract}
Since 2019, Capital Bra is the most streamed German musician, one of the top five most streamed German musicians internationally and the only German artist in the twentieth and twenty-first centuries who has produced all in all twelve number one chart hits during one year in Germany, Austria and Switzerland (Schmidt 2019, Skrobala 2019). This article uses a corpus with approximately 100,000 tokens (word forms, punctuation, digits and abbreviations) of lyrics from the albums of four German rappers with a Polish or Russian background for an analysis of the multilingual relationships in such musicians' lyrics and how their Slavic vocabulary may integrate into the German language. The results reveal surprisingly large dimensions of multilingual interdependence, including incorporation of vocabulary from English, Arabic and Turkish, as well as the grammatical handling of the Slavic first learned language (L1) in multilingual context. An additional point of the study is the stylometric clustering of the lyrics with the free programming environment for statistical computing called $\mathrm{R}$, which shows relationships between texts and rappers.
\end{abstract}

In the past several years, since the criticised Nobel Prize in Literature was awarded to Bob Dylan (2016) and the first Pulitzer Prize for Music was awarded to a rapper (Kendrick Lamar in 2018), not only modern song lyrics in general, but rap music lyrics in particular started gaining broad public attention worldwide. The same trend was observed in Germany in 2018, when a rapper from the Russian speaking minority, Capital Bra, scored eight number-one chart hits in the course of only one year and thus became the most popular musician in twenty-first century Germany. Rap is a popular music genre which mostly characterises through rhythmic speech in combination with an electronic produced beat and/or accompaniment of classical music instruments as guitar or piano. German linguists, sociologists and researchers from other disciplines have already taken initial steps in the research of German rap in the twentyfirst century, as the conference "Hip Hop Symposium Mannheim" showed in 2018 (Popakademie Baden-Württemberg GmbH 2018). It was hosted by the Bundeszentrale für politische Bildung (Federal Center for Civic Education), the Pop Akademie Baden-Württemberg (Pop Academy Baden-Württemberg) and Institut für Deutsche Sprache Mannheim (Institute for German Language Mannheim). However, the participating rappers (Jan Delay and Samy Deluxe) have been active in the German hip hop scene for more than twenty years and 
do not have a young target audience anymore. This indicates that the symposium largely discussed aspects of rap that are not relevant to the latest generation of music consumers. The subject of German rappers with a Slavic background remains hitherto scientifically unexplored.

\section{Previous research}

Until the beginning of the 2010s, it was widely believed that Deutschrap (German rap) is dominated by musicians with a Turkish or Arab background (e.g. Chemeta 2013, 38; Loentz 2006, 34; Simpson 2020, 61), who often use their L1 (First Language) or L2 (Second Language) alongside German in their songs. This is also demonstrated by the top rankings in the Youth Word of the Year vote (Langscheidt 2019) for the years 2012 to 2014: Yalla [Come on!], Babo [boss, father], Hayvan [beast]. The initiator of the voting is German publishing company which specialises in language reference works. For example, the word Babo first appeared in the German rap scene in the songs of the rapper Haftbefehl [warrant] from a Turkish-Kurdish family (Heine 2013). For the streaming charts in 2018, the Bundesverband Musikindustrie (Federal Association of the Music Industry) in Berlin noted that the most popular German-language pieces of music are rap. The most popular song was "Neymar" by Capital Bra and Ufo361.

Russian was mentioned as one of the languages in Deutschrap for the first time in research literature in 2018 (Cotgrove 2018, 79). Cotgrove as well mentions Ukrainian, which is unfortunately not proven in the analysed lyrics (ibid.). This is not meant as criticism of the paper, because Cotgrove's main question was not the usage of Slavic languages in Deutschrap, but the comparison of linguistic behaviour in the lyrics of German rappers with Kurdish, Turkish, Russian, Ukrainian, Lebanese and Afro-German backgrounds. One of the most important findings is the difference from the language usage in US Afro-American rap in which multilingualism is less pronounced and the musicians mostly do not refer to their origin or their identity through lexical markers the way artists in Deutschrap more frequently do (ibid., 90). US Afro-American rappers more often cite the city or district from which they originate. From this point of view there might be a better correlation between Deutschrap and US Hispanic rappers, but this topic was not taken up in the paper. Polish is an unexplored topic in existing linguistic research on Deutschrap.

A legitimate question in this context is whether this is a marginal phenomenon or if this music reaches a wider audience. I have three reasons for believing the topic discussed in this paper to be of wider relevance. Firstly, the four musicians are the most popular German rappers on YouTube with a Polish or Russian background. The most viewed videos are made by Capital Bra. His music video "One Night Stand" has now over 107 million views. The video "Magisch" (Magic) by Olexesh has more than 84 million views, "Tabledance" by Schwesta Ewa over nine million views and "Alles läuft nach Plan" (Everything is going as planned) by Krime more than one million views. All the videos were uploaded in 2018-2019. Secondly, the artists are not only popular on YouTube, but they are professional musicians. They are earning money through selling albums and streaming songs. Recently Capital Bra became the most popular musician of the twentieth and twenty-first centuries in Germany. He in particular earns 
a lot of attention on streaming services, which are predominantly used by millennials (Hodak 2018). Thirdly, All four artists are either signed to Universal Music Group or to labels which have direct partnerships with Universal or are their sub-labels. They are the first German rappers with a Slavic background who have become musicians of this global label. The outstanding success of the musicians in Germany and the partnership with such a major global player as Universal shows that their music plays a significant role in current German pop culture. This paper will discuss whether the musicians are contributing new language behaviour trends to Deutschrap because of their Slavic background.

\section{Research design}

The aim of this article is not to investigate all German rappers with a Slavic background and the language use in their lyrics, but to collect the first relevant data on this topic, discuss its character, search for new phenomena and offer some preliminary interpretations. The resulting questions refer to the newest multilingual trends in Deutschrap. The goal is not only to show the characteristics of the multilingual behaviour, but to investigate (i) the reasons behind it and (ii) what kinds of messages can be delivered through a certain language behaviour. Additional questions would be (iii) which influences can be determined in the context of world view or socio(-political) value system and (iv) which socio(-linguistical) role these lyrics play among its audience. Regarding questions (i), (iii) and (iv), I have paid particular attention to the levels of interlingual transfer. Regarding (ii), I have analysed which messages the musicians are transmitting through their lyrics, specifically in the context of politics.

To investigate these questions, I have compiled my online language corpus named DRaKoSlav with the songs of four German musicians with a Polish or Russian background. DRaKoSlav runs on the Sketch Engine platform, where the corpus is open for any invited user. DRaKoSlav includes 12 albums of the four selected musicians which were released between the start of their commercial career, mainly in the beginning of the 2010s, and the first half of 2019 . Altogether there are 230 texts, or 109,138 words, or 137,798 tokens. In addition to the analysis tools of Sketch Engine, like word frequency lists and concordance, I have used a simple statistical analytics in Microsoft Excel and the stylistic research package for the R-Software called stylo.

\section{Background information on the musicians}

Olexesh (OL) was born in 1988 as Olexij Kosarev in Ukraine and moved to Germany with his mother in 1993. His home label 385idéal is located in Frankfurt and was founded by the Bosnian-German rapper Celo and MoroccanGerman rapper Abdi. Olexesh is originally from Darmstadt, thirty kilometers from Frankfurt.

Capital Bra (CB) was born in 1994 as Vladislav Balovatsky in Siberia in Russia. More specific information about his birthplace is not available. He moved with his family to Ukraine in the late 1990s and then in the early 2000s to Berlin. At the moment, he is signed to his own Berlin-based label Bra Musik. He was formerly signed to such labels as Team Kuku, which he established along with his colleague the Lebanese-Kurdish-German rapper King Khalil, and Ersguterjunge, 
a sub-label of Sony Music owned by Bushido, one of the most popular German rappers of the 2000s and early 2010s, who is of Tunisian-German origin.

Schwesta Ewa (SE) was born in 1984 as Ewa Malanda in Poland and moved around the turn of the millennium to Germany. She is a musician of the Frankfurt-based label Alles oder Nix established by the Kurdish-German Rapper Xatar.

Krime (KR) is the youngest rapper in this study. He was born 2001 as Kevin Wrzezinski in Germany, but his family moved between Poland and Germany for the first nine years of his life. Finally, they settled in Freiburg about $300 \mathrm{~km}$ from Frankfurt. Since 2019 he has been signed to the label 385idéal.

\section{Multilingualism and rap lyrics}

To discuss multilingualism and multicultural identity in the lyrics of selected German rappers with a Slavic background in the context of the four aspects formulated above. These include (i) possible reasons behind the multilingual behaviour; (ii) what kinds of messages can be delivered through this language behaviour; (iii) which influences can be determined in the context of worldview or socio-political value system; (iv) which socio-linguistic role these lyrics play among its audience

The analysis of the DRaKoSlav corpus revealed fourteen languages in the songs of Capital Bra, eleven for Olexesh, eight for Schwesta Ewa and seven for Krime. To illustrate how this high number of languages can work in one song, I have chosen two quotes, as shown in table 1.

Table I. Language use by Capital Bra and Olexesh.

\begin{tabular}{|c|c|c|}
\hline Line & Original & English translation \& [original language] \\
\hline \multicolumn{3}{|c|}{ Capital Bra “Was 2, hol 10", album “Makarov Komplex" (2017) } \\
\hline CBI & $\begin{array}{l}\text { "Bras, die für gut Geld gut auf dich } \\
\text { aufpassen, }\end{array}$ & $\begin{array}{l}\text { Bros [RUS], getting good money for } \\
\text { looking good after you [GER], }\end{array}$ \\
\hline CBII & Aber ich bin Ukrainer, я убью за брата, & $\begin{array}{l}\text { But I am Ukrainian [GER], I will kill for } \\
\text { my brother [RUS], }\end{array}$ \\
\hline CBIII & $\begin{array}{l}\text { Но тихо едешь, дальше будешь, } \\
\text { говорит мне мама, }\end{array}$ & $\begin{array}{l}\text { Slowly but surely, tells me my mother } \\
\text { [RUS], }\end{array}$ \\
\hline CBIV & $\begin{array}{l}\text { Trotzdem brauch' ich Para, brechen aus, } \\
\text { Räubeleiter" }\end{array}$ & $\begin{array}{l}\text { But I need [GER] money [TK], break out, } \\
\text { crossed ladder [GER] }\end{array}$ \\
\hline \multicolumn{3}{|c|}{ Olexesh “Master”, album Master (2015) } \\
\hline OLI & $\begin{array}{l}\text { “Ich kenn' Jungs, die ballern direkt von } \\
\text { Harleys, }\end{array}$ & $\begin{array}{l}\text { I know guys, they shoot right from their } \\
\text { harleys [GER], }\end{array}$ \\
\hline OLII & $\begin{array}{l}\text { El mi mejor, Salvador, anvisier den } \\
\text { Matador, }\end{array}$ & $\begin{array}{l}\text { I am the best, Salvador [ESP], I target the } \\
\text { matador [GER], }\end{array}$ \\
\hline OLIII & Ich hab' nur ein Ziel vor Augen, & $\begin{array}{l}\text { I have only one goal in front of my eyes } \\
\text { [GER], }\end{array}$ \\
\hline OLIV & Please open the door" & Please open the door [ENG] \\
\hline
\end{tabular}

Capital Bra uses three languages in four lines - German, Russian and Turkish. There are examples where the whole lines are in one language (CBIII), separated fifty-fifty in two languages (CBII) or have insertion of just one word from 
a different language (CBI, CBIV). In the case of one-word-insertions, it has to be mentioned that while para (CBIV) is standard Turkish, Bra (CBI) is nonstandard Russian or is not Russian at all. The first reason for this hypothesis is the spelling in Latin and not in the Cyrillic alphabet. The Latin version is the dominant spelling in the official sources of Capital Bra. The second reason is that the word comes from the Russian word 6pam (brother) (Fasmer 1996, 207), but the form bra or 6pa only has the meaning of "sconce" (light fixture) in Russian (Fasmer 1996, 204) and not the meaning "brother". Bratan or bra means in the lyrics of Capital Bra "dude" or "fellow" (Mešić 2018, 451). In the excerpt from Olexesh, we can also see three languages: German, Spanish and English. He is using languages here in almost the same way as Capital Bra; either one language per line or in a fifty-fifty combination.

Table 2. Number of languages used in a song.

\begin{tabular}{|l|r|r|r|r|}
\hline & \multicolumn{1}{|c|}{ Olexesh } & \multicolumn{1}{|c|}{ Scwesta Ewa } & \multicolumn{1}{c|}{ Krime } & \multicolumn{1}{c|}{ Capital Bra } \\
\hline monolingual & 0 & 1,905 & 4,878 & 0 \\
\hline bilingual & 11,25 & 14,286 & 21,951 & 20 \\
\hline trilingual & 48,75 & 30,476 & 36,585 & 0 \\
\hline 4 or more & 40 & 53,333 & 36,585 & 80 \\
\hline
\end{tabular}

\section{Distribution of language combinations}

As we can see in table 2 only two artists - Capital Bra and Schwesta Ewa - have monolingual texts and even in this case these kinds of texts are rare, comprising less than 5\% of all analysed songs. Even bilingual lyrics are not common, ranging between 11 and $21 \%$ of all entries. Trilingual lyrics are more popular, characterising $30-49 \%$ of the analysed texts. The most common category contains lyrics in four or more languages: $36,5-80 \%$.

Table 3. Most frequent languages and the percentage of their appearence in the lyrics.

\begin{tabular}{|l|r|r|r|r|}
\hline & Olexesh & Capital Bra & Schwesta Ewa & Krime \\
\hline GER & 100 & 100 & 100 & 100 \\
\hline ENG & 97,5 & 60 & 37,6 & 40 \\
\hline SL-L1/L2 & 78,8 & 90,5 & 70 & 40 \\
\hline AR & 11,2 & 38,1 & 44 & 40 \\
\hline TK & 11,2 & 52,4 & 59 & 60 \\
\hline
\end{tabular}

It is not surprising that all lyrics contain German (see table 3). Olexesh uses English in $97,5 \%$ of his songs. In this respect he is different from the other three musicians, who use English in $40-60 \%$ of their lyrics. Olexesh, Capital Bra and Schwesta Ewa use their Slavic L1/L2 in 70-90\% of their songs. Krime, however, only does so in $40 \%$ of his songs. Arabic is used by all artists, with the exception of Olexesh, in $40-47 \%$ and Turkish in $51-60 \%$ of the analysed songs. 
Table 4. Twenty Most frequent nouns in the DRaKoSlav corpus.

\begin{tabular}{|l|r|r|}
\hline Lemma & $\mathrm{N}$ & Per Mill. \\
\hline bra & 651 & $4,724.30659$ \\
\hline geld & 269 & $1,952.13283$ \\
\hline bratan & 226 & $1,640.08186$ \\
\hline $\mathrm{m}$ & 211 & $1,531.22687$ \\
\hline bruder & 201 & $1,458.65687$ \\
\hline gucci & 179 & $1,299.00289$ \\
\hline tag & 165 & $1,197.4049$ \\
\hline $\mathrm{n}$ [ein/einen] & 163 & $1,182.8909$ \\
\hline para & 161 & $1,168.3769$ \\
\hline kopf & 148 & $1,074.03591$ \\
\hline leben & 138 & $1,001.46591$ \\
\hline benz & 133 & 96518092 \\
\hline schein & 132 & 95792392 \\
\hline jungs & 128 & 92889592 \\
\hline sex & 125 & 90712492 \\
\hline straße & 123 & 89261092 \\
\hline berlin & 119 & 86358293 \\
\hline zeit & 115 & 83455493 \\
\hline ewa & 111 & 80552693 \\
\hline darby & & 79101293 \\
\hline
\end{tabular}

Among the twenty most used nouns in Table 4, I have detected three languages; Russian (light grey), German (dark grey) and Turkish (solid frame). In the first and third position is a lemma with the same semantic meaning - brother. It is expressed through Russian братан - in the corpus and in the lyrics in Latin graphemes bratan - and bra, which has already been discussed above. Other non-German lemma are para (money) and darby.

Table 5. Transfer dynamics of the likely etymology of the word "darby".

\begin{tabular}{|l|l|l|}
\hline German $\rightarrow$ & Turkish $\rightarrow$ & German \\
\hline reinhauen $\rightarrow$ & darbe $\rightarrow$ & darby \\
\hline (Eng.: to give a kick) & (Eng.: kick) & (Eng.: tilidine respectively something that gives a kick) \\
\hline
\end{tabular}

The origin of darby has not been completely clarified yet. This word is used in the lyrics as the synonym of tilidine, an analgesic which is often misused as an illegal drug. The possible origin can be the Turkish word darbe, which means chop, slash, hit, punch. In this special context of drug consumption and German-Turkish language contact in Germany, it might be a German loanword that was literally translated into Turkish and then came with a phonetic/morphologic modification of the flexional affix back to German. The other twelve of the twenty most frequent nouns are German. The most frequent German noun is Bruder [brother]. The non-marked nouns are proper names or interjections, like Berlin or $\mathrm{mmmh}$. 
Table 6. Non-conforming single words and two-word-phrases in comparison with the German Reference Corpus.

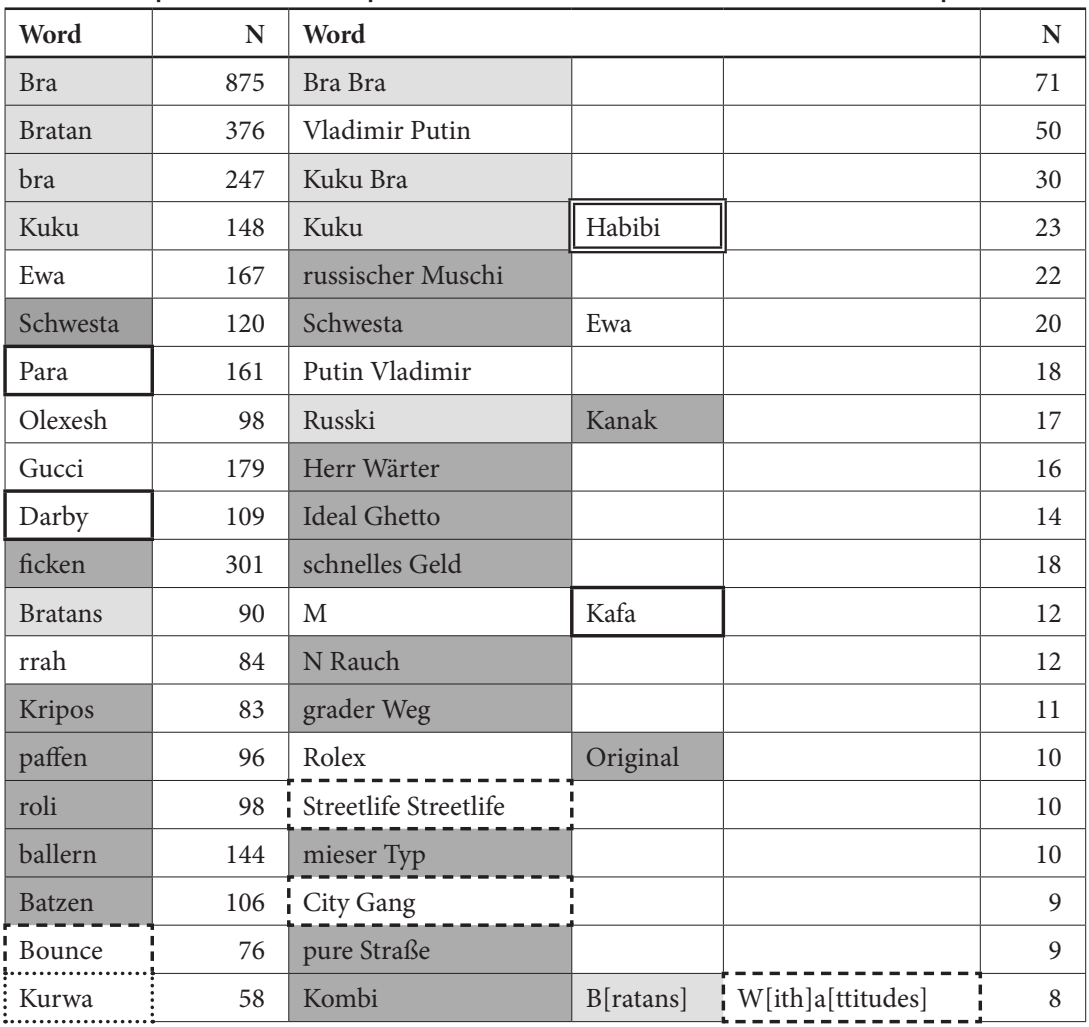

In this category (table 6), I used SketchEngine to automatically generate and compare the DRaKoSlav dataset to the German reference corpus deTenTen13, identifying the words and word pairs that are unusual in DRaKoSlav compared to the German dataset. Here we can observe Russian (light grey) loanwords in the top positions. The German (dark grey) results constitute less than $50 \%$ of the total. Turkish (solid frame) and English (dashed frame) results are represented less frequently. Other new contact languages here apart from English are Polish (dotted frame) and Arabic (double-lined frame) which are represented by one match in each case. The non-marked results are proper names or interjections.

\section{Clustering and concordance}

All lyrics were analysed and clustered with stylo-package (Eder, Kestemont, and Rybicki 2016) for R. The package measures Eder's Delta Distance between all texts. The DRaKoSlav-cluster-network-analysis with R-package stylo has shown three big sub-clusters which are defined through extreme points. The extreme points are lyrics which are effectively the starting points of the subclusters. The first sub-cluster consists in large part of texts by Olexesh, Schwesta Ewa, Capital Bra and Krime. The second sub-cluster is dominated by lyrics 


\begin{tabular}{|c|c|c|c|c|c|c|c|c|c|c|c|c|c|c|c|c|c|c|c|c|}
\hline 营 & 声 & & & & & & & 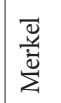 & & & 害 & 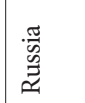 & & 岕 & & & 泀 & & & \\
\hline 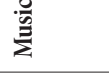 & Өૈ & ๑ै & లి & లి & లి & లి & $\overrightarrow{0}$ & சै & 0 & 匆 & 沾 & Oै & $\overrightarrow{0}$ & சै & $\overrightarrow{0}$ & $\overrightarrow{0}$ & சै & ชి & $\overrightarrow{0}$ & சै \\
\hline 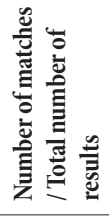 & $\stackrel{\infty}{\stackrel{\infty}{n}}$ & $\frac{\infty}{\stackrel{\infty}{2}}$ & $\stackrel{\infty}{\stackrel{\infty}{=}}$ & $\stackrel{\infty}{\stackrel{\infty}{\digamma}}$ & $\stackrel{\infty}{\stackrel{\infty}{\sim}}$ & $\stackrel{\infty}{\stackrel{\infty}{\sim}}$ & $\stackrel{\infty}{\stackrel{\infty}{\sim}}$ & $\stackrel{m}{=}$ & $\stackrel{m}{=}$ & $\stackrel{m}{=}$ & $\Xi$ & $\stackrel{N}{=}$ & $\begin{array}{l}\tilde{O} \\
\infty \\
\stackrel{+}{+}\end{array}$ & $\stackrel{m}{=}$ & $\stackrel{m}{=}$ & $\stackrel{m}{=}$ & 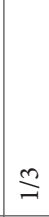 & $\stackrel{m}{=}$ & $\stackrel{m}{=}$ & $\stackrel{\Xi}{\Xi}$ \\
\hline 害 & + & + & +1 & +1 & + & + & + & ' & +1 & & 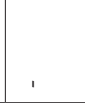 & + & 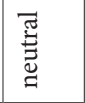 & ' & + & +1 & + & + & + & \\
\hline 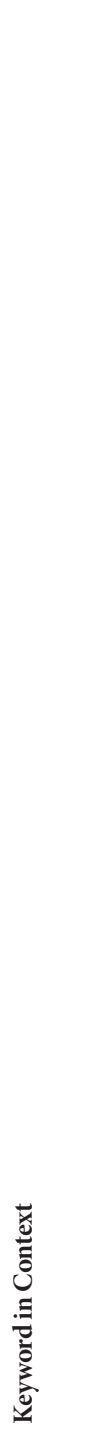 & 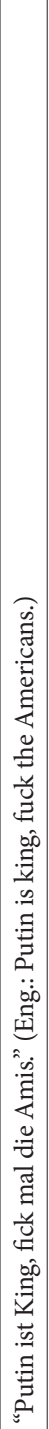 & 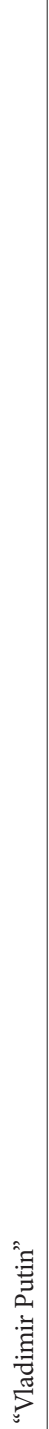 & 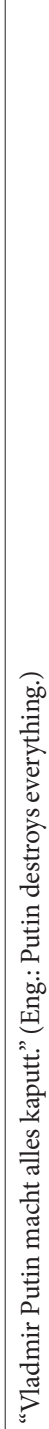 & 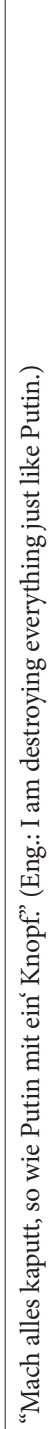 & 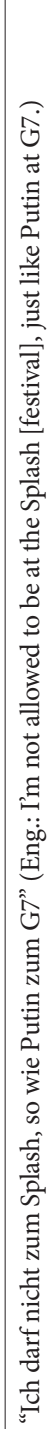 & 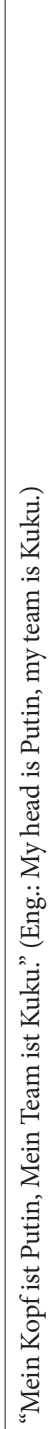 & 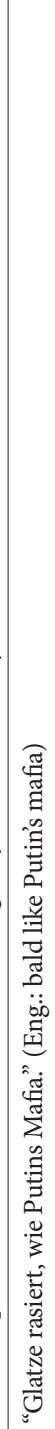 & 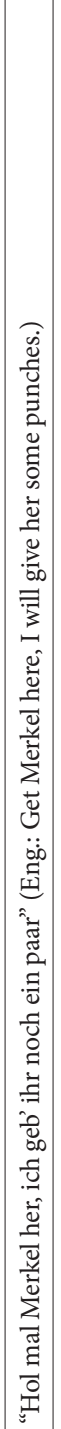 & 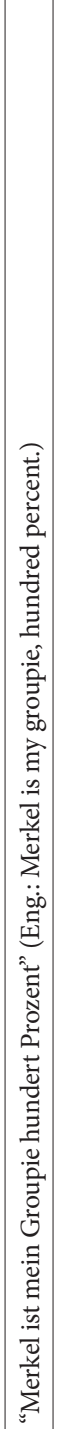 & 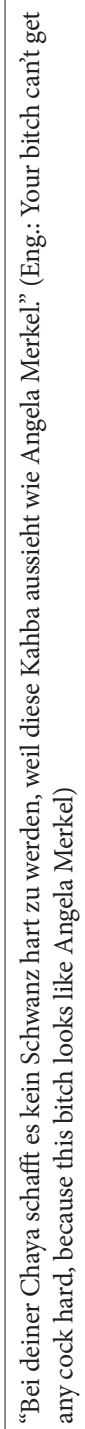 & 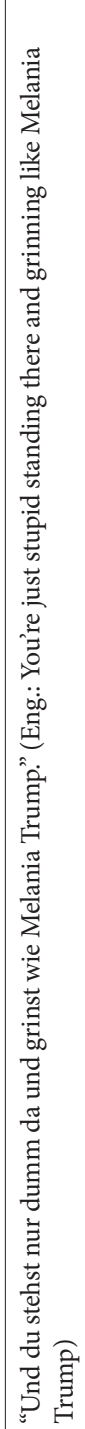 & 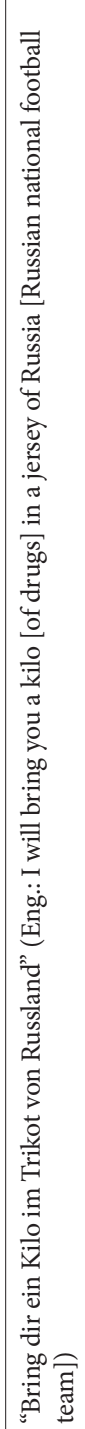 & 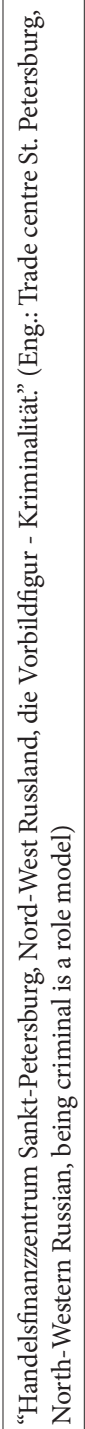 & 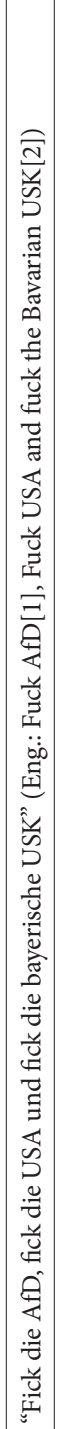 & 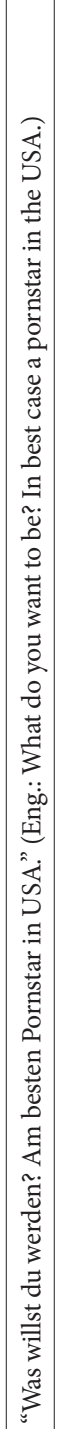 & 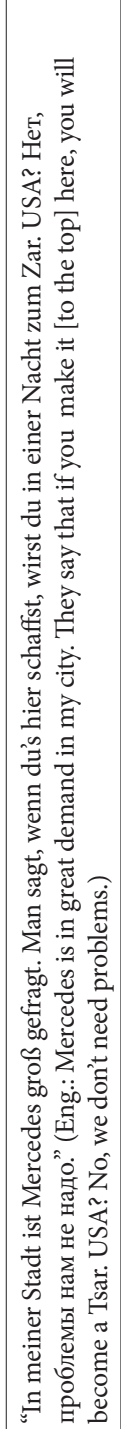 & 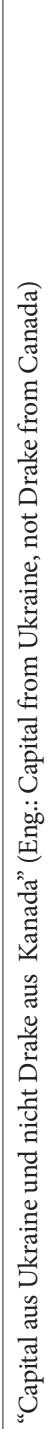 & 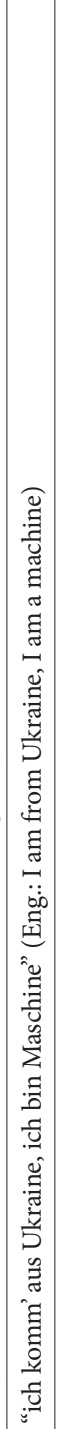 & 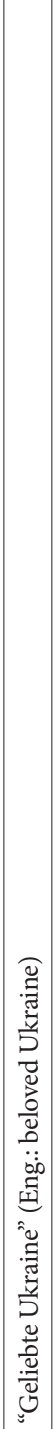 & 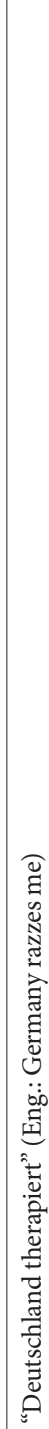 \\
\hline
\end{tabular}




\begin{tabular}{|c|c|c|c|c|c|c|c|c|c|c|c|c|c|c|c|c|c|c|c|c|c|c|c|c|}
\hline & & & & & & & & & & & & $\begin{array}{l}\overrightarrow{\widetilde{G}} \\
\frac{\overrightarrow{\mathrm{O}}}{0}\end{array}$ & & & & 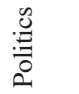 & & & & & & & & \\
\hline ชิ & ชै & சి & $\underline{\approx}$ & 幾 & $\underline{z}$ & $\underline{\mathfrak{z}}$ & $\overrightarrow{0}$ & $\overrightarrow{0}$ & $\overrightarrow{0}$ & $\overrightarrow{0}$ & $\overrightarrow{0}$ & జै & है & 虫 & 岳 & 己ै & $\because$ & $\overrightarrow{0}$ & $\overline{0}$ & & & & & \\
\hline$\Xi$ & $\stackrel{ }{\Xi}$ & $\stackrel{\triangleq}{\triangleq}$ & $\stackrel{\triangleq}{\triangleq}$ & $\stackrel{ }{\Xi}$ & $\underset{\sim}{\stackrel{\curvearrowright}{N}}$ & $\stackrel{\Xi}{\Xi}$ & $\stackrel{\Xi}{\Xi}$ & $\stackrel{\curvearrowright}{\curvearrowright}$ & $\stackrel{\triangleq}{\triangleq}$ & $\stackrel{\triangleq}{\triangleq}$ & $\stackrel{\Xi}{\triangleq}$ & $\triangleq$ & $\stackrel{\Lambda}{\mathrm{N}}$ & $\frac{N}{m}$ & $\triangleq$ & $\stackrel{n}{a}$ & $\stackrel{n}{=}$ & $\stackrel{n}{=}$ & $\stackrel{n}{=}$ & & & & & \\
\hline ' & ' & ' & + & + & + & 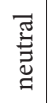 & + & + & + & $\begin{array}{l}\overrightarrow{\widetilde{E}} \\
\stackrel{\Xi}{\Xi} \\
\end{array}$ & 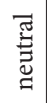 & & +1 & & $\begin{array}{l}\overrightarrow{\widetilde{E}} \\
\stackrel{\Xi}{\Xi} \\
\end{array}$ & I & , & , & ' & & & & & \\
\hline 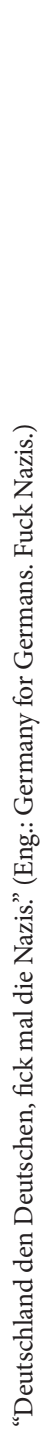 & 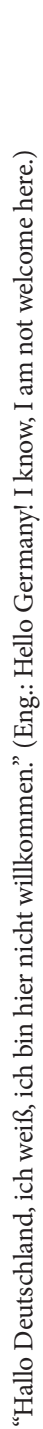 & 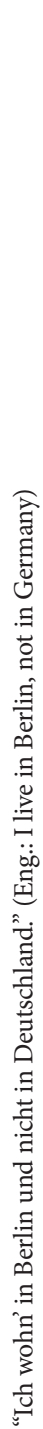 & 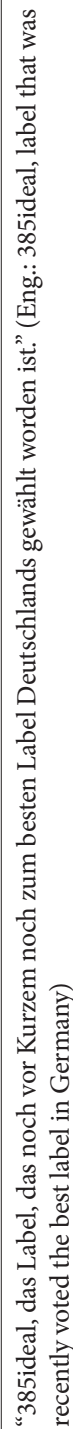 & 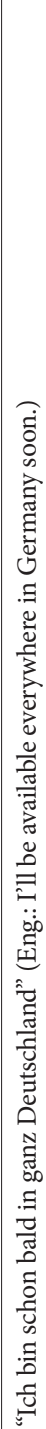 & 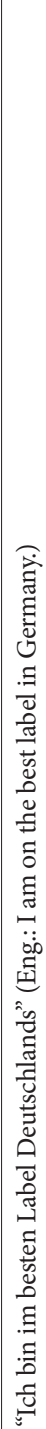 & 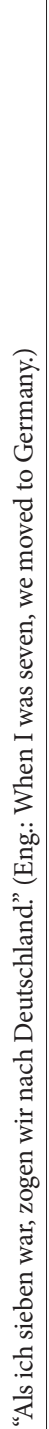 & 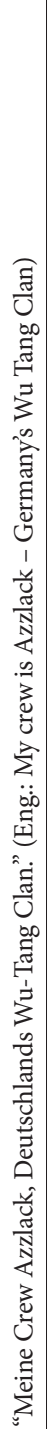 & 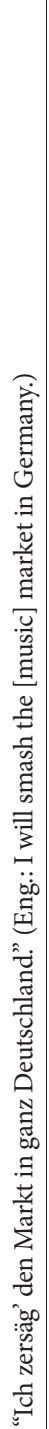 & 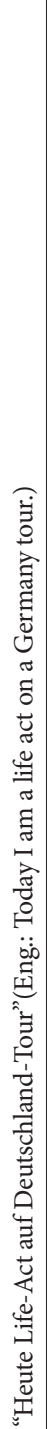 & 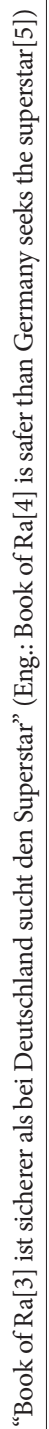 & 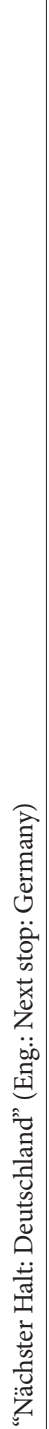 & 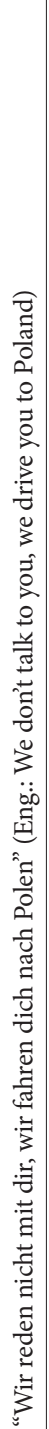 & 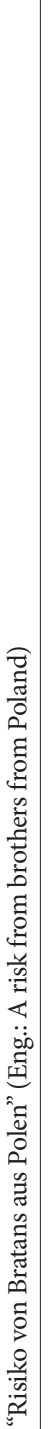 & 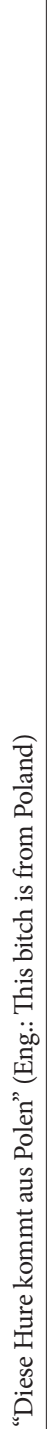 & 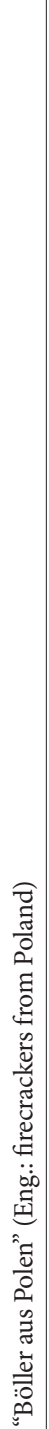 & 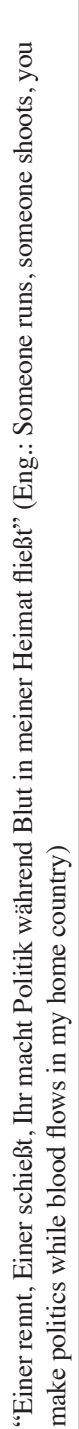 & 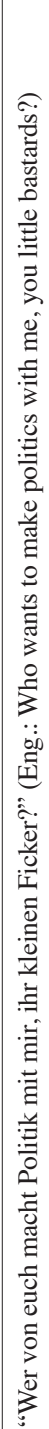 & 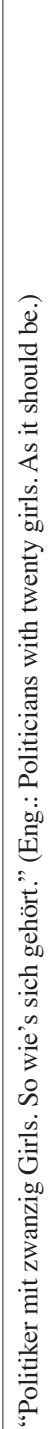 & 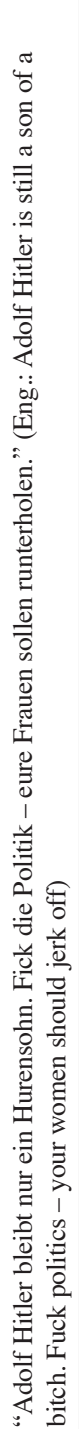 & 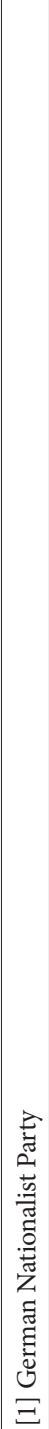 & 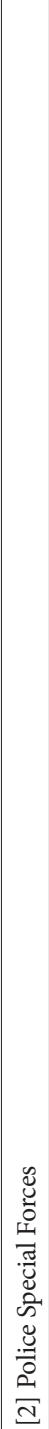 & 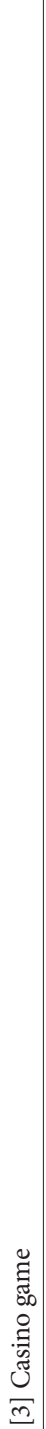 & 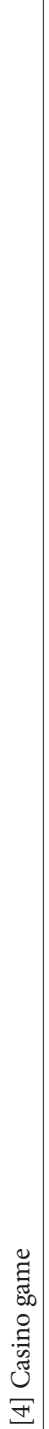 & 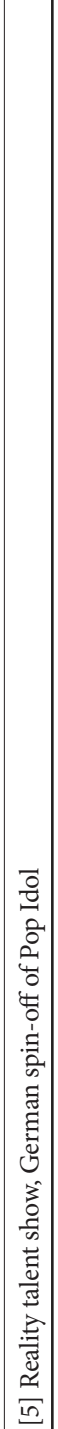 \\
\hline
\end{tabular}


from Capital Bra with comparatively few lyrics from other artists. The third is exclusively constituted by Capital Bra's songs. The assignment of the songs to each other was made automatically, as well as the assignment of the extremes and the sub-clusters.

To examine the socio-linguistic dimension of the DRaKoSlav corpus (see table 7), I have searched for concise keywords in context (KWIC) such as Putin, Merkel, Trump, Russland [ Russia], Ukraine, Deutschland [Germany], USA and all nouns starting with Politik... [Political...]. The results are presented in table 7.

\section{Discussion}

The nature of the non-German language elements the artists are using is a relevant point to discuss. As has been showed, there are some Slavic loanwords used in the lyrics. While Bratan [brother] exists in Russian, the lexemes Bra or kuku do not exist in the meaning intended by the artists. Bra is clearly an abbreviation of Bratan, but kuku is intended to mean pay attention in Russian or Albanian - for this phrase are various statements of the artist about the origin and the meaning available (Chapter One Music 2019, Richter 2016). This meaning does not exist in Russian or Ukrainian. The only meaning it could have is $\kappa y-\kappa y$, which is a game mostly played with babies and is equivalent to peek-a-boo in the English-speaking cultural environment. $K y-\kappa y$ in Russian is an interjection and can be translated as I see you. The Polish lexemes used by all four musicians are in some cases colloquial or vulgar (for example Kurwa [bitch]), but the matches still correspond to standard language use in Poland. The frequent use of Arabic and Turkish in the songs beyond German, English, Russian and Polish shows that the conception of Russian, Ukrainian, Polish or Turkish diasporas (or other isolated groups of migrants respectively) is obsolete. The musicians, who can provide youth with a role model, as their popularity shows, represent a new hybrid form of identity. The language behaviour is forming a model of social and ethnic self-identification which includes a large number of ethnic groups, including Germans.

The stylometric clustering showed varied relationships between the lyrics. All 230 analysed songs have been clustered automatically into three sub-clusters. One of three sub-clusters is the general one where all four musicians are represented in nearly the same proportion. The second sub-cluster also represents all four musicians, but the lyrics of Capital Bra dominate here. The third sub-cluster consists only of Capital Bra's lyrics. One possible interpretation here could be that the other three artists, with the exception of Capital Bra, were socialised in western Germany, whereas Capital Bra was socialised in Berlin, particularly in the Hohenschönhausen district in the eastern part of the city, which is known as a working class neighbourhood on the outskirts of the city. The second possible influence could be the frequent change of Capital Bra's labels. The best example here would be the third sub-cluster, where more than a half of the lyrics are from the album Allein [Alone], which was produced at erisguterjunge, the label of the Tunisian-German rapper Bushido. It was the last album of Capital Bra on this label, which he produced in the middle of a highly publicised legal conflict about leaving his label. At the same time, it is the album from the whole corpus which has the most monolingual and bilingual lyrics. Capital Bra's lyrics are obviously not only dominant as 
a part of all three sub-clusters, but also as the extreme points which are the beginnings of all sub-clusters. The reason for this could be the productivity of the musician. His songs constitute almost half of the corpus (104 of 230 lyrics). Of course, the sub-clusters could be formed differently if the corpus were more balanced, but this would require the addressing the thorny task of choosing data for a balanced corpus and the question of how representative it would be. For the moment, the corpus includes all lyrics written and published by the four artists on their official albums released between 2010 and the first part of 2019.

The analysis above demonstrated that the lyrics of the four artists are multilingual and include new trends of using Slavic lexis and mixing these with Turkish and Arab vocabulary. But there is more to be said. Strictly bilingual lyrics are in the minority (11-21\%). In the majority of the lyrics (30-80 \%), I have detected three or more languages. In this constellation, German is used by all four rappers. It is noteworthy that English plays an important role just for one musician: Olexesh. He uses it more often than Russian, his Slavic L1 or rather L2. The other three musicians - Capital Bra, Schwesta Ewa and Krime - use their Slavic language as often as English or even more frequently (40-80 $\%)$. It is remarkable that these three artists are also using Arabic and Turkish at least as often as English. The research provides concrete evidence for significant patterns of language behaviour. While Olexesh has stated in some interviews (TV Strassensound 2012) that the US-rapper Eminem is one of his main inspirations, the other three are more influenced by Deutschrap, which is dominated by rappers with an Arabic or Turkish background. This study also considers the messages the musicians are transporting via their songs. Regarding the use of possibly political keywords, Capital Bra's political opinion can be described as pro-Russian, pro-Putin, anti-US, and anti-German (national) politics, but proBerlin. Especially the point of view concerning Russian politics expressed in his songs contradicts his claim that the music is not political (Team Kuku 2017). Olexesh's political positioning cannot be defied as clearly as Capital Bra's, but he has tendencies towards a pro-US point of view. This fact also corresponds with his language use behaviour. But one common aspect of both musicians is the fact that they do not use Ukrainian at all despite their Ukrainian background. At the same time, their statements about Ukraine in lyrics and interviews are exclusively positive. The lyrics by Schwesta Ewa and Krime cannot be classified as political. The number of their political statements is too small. The lines about Poland are also not political, but more often negative than positive from the semantic point of view. Unlike their Ukrainian colleagues, they are using their Slavic background language, which is Polish.

This preliminary study only presented a sample of the most popular German rappers with a Russian or Polish background. In order to get more representative results, future research will involve a corpus upgrade to include all lyrics by the musicians and not only with texts from their albums. This would mean that lyrics from mix tapes, featuring songs, demo tapes and singles, would also be included. It will also be necessary to include rappers with a South Slavic, specifically Bosnian, background. This addition would contribute another dimension to the study, religion, because most Bosnian-German rappers are Muslim 
and may have more in common with Turkish- and Arabic-German rappers than their colleagues with an East- or West Slavic background.

Another essential question would be the quality of the Slavic languages represented in the songs, which may give enough data to determine to which level of knowledge it could belong - L1, L2 or heritage speaker - and how this language use may influence the public online communication to and of their audience.

\section{References}

Chapter One Music. n.d. "Capital Bra - Kuku Bra”, https://chapterone-music.com/releases/capital-bra-kuku-bra/ (accessed 28 October 2019).

Chemeta, David. 2013. "Deutsche Identität, Kultur und Sprache im deutschen Rap", Zeitschrift fuer Ethnologie 138 (1), 37-54.

Cotgrove, Louis Alexander. 2018. "The Importance of Linguistic Markers of Identity and Authenticity in German Gangsta Rap”, Journal of Languages, Texts, and Society 2, 67-98.

Eder, Maciej, Mike Kestemont, and Jan Rybicki. 2016. "Stylometry with R: A Package for Computational Text Analysis”, R Journal 8 (1): 107-121, https://journal.r-project.org/archive/2016/ RJ-2016-007/RJ-2016-007.pdf.

Fasmer, Maks. 1996. Ėtimologičeskij slovar' russkogo jazyka. Sankt-Peterburg: Azbuka.

Heine, Matthias. 2013. "Babo ist zazaisch”, Welt, 26 November 2013. Https://www.welt.de/print/ die_welt/kultur/article122257240/Babo-ist-zazaisch.html.

Hip Hop Symposium. n.d. “\#Sprecher”, Http://www.hiphop-symposium.de/\#Sprecher (accessed 28 October 2019).

Hodak, Brittany. 2018. "New Study Spotlights Gen Z’s Unique Music Consumption Habits”, March 2018 in Forbes Magazine Online. https://www.forbes.com/sites/brittanyhodak/2018/03/06/newstudy-spotlights-gen-zs-unique-music-consumption-habits/\#1d4a3ecf42d0 (accessed 28 October 2019).

Langscheidt. n.d. "Jugendwort des Jahres", https://www.langenscheidt.com/jugendwort-des-jahres (accessed 28 October 2019).

Loentz, Elizabeth. 2006. "Yiddish, Kanak Sprak, Klezmer, and HipHop: Ethnolect, Minority Culture, Multiculturalism, and Stereotype in Germany”, Shofar 25 (1), 33-62.

Mešić, Sanela. 2018. "Fremdwörter in Der Jugendsprache vor 20 Jahren und Heute: Aktuelle Perspektiven internationaler Forschung", Jugendsprachen, 443-454.

Popakademie Baden-Württemberg GmbH. 2018. "Popakademie richtet erstes deutsches Hiphop Symposium aus”, https://www.popakademie.de/de/presse/popakademie-richtet-erstesdeutsches-hiphop-symposium-aus/u/1010/ (accessed 9 October 2020).

Richter, Louis. 2016. “Interview mit Capital Bra über 'Kuku Bra”', Rap.de, February 10, 2016. https://rap.de/c37-interview/74125-interview-mit-capital-ueber-kuku-bra/.

Schmidt, Dominik. 2019. "Capital Bra stellt neuen Rekord auf: in Deutschland meistgestreamter Interpret aller Zeiten”', Rolling Stone, 2 May 2019, https://www.rollingstone.de/capital-bra-stellt-neuenrekord-auf-in-deutschland-meistgestreamter-interpret-aller-zeiten-1699373/.

Skrobala, Jurek. 2019. "Hip-Hopper Capital Bra hat in Deutschland mehr Charterfolge als die Beatles - wie kann das sein?” Stern, 17 August 2019, https://www.stern.de/neon/feierabend/musik-literatur/ capital-bra-hat-in-deutschland-riesenerfolg--wie-kann-das-sein--8848692.html.

Simpson, Patricia Anne. 2020. “Gendered identities and German Islamophobias," Journal of Contemporary European Studies 28 (1), 57-69.

Team Kuku. 2017. “Capital Bra - Abendshow im rbb 28.09.2017”. Filmed September 2017 at rbb TV-studios, Berlin, GER. Video, 6:28, https://www.youtube.com/ watch? $\mathrm{v}=7 \mathrm{uNSJInDXDg} \& \mathrm{t}=270 \mathrm{~s}$.

TV Strassensound. 2012. "Olexesh: Deutscher Eminem - TV Strassensound - On Point - German Eminem", Filmed November 2012 on the street, Frankfurt am Main, GER. Video, 1:31, https:// www.youtube.com/watch?v=kd2DYj87Qe8. 